\title{
TAX REVENUE OF NEPAL: ASSESSING THE IMPACT ON GDP
}

\author{
Khom Raj Kharel, PhD*
}

\begin{abstract}
This study examines the economic impact of tax revenue and economic growth of Nepal, from 2000 to 2018. In order to attain the objectives, relevant time-series secondary data were collected from the Economic Survey published by Ministry of Finance, Quarterly Economic Bulletin published by Nepal Rastra Bank, Revenue Department and previous works done by scholars. The collected data has been analyzed by using linear regression model. The results display that tax revenue and total revenue has a positive significant effect on GDP. The trends of tax revenue has signified the positive trends but not sufficient to meet the government expenditure of Nepal.
\end{abstract}

Keywords: Tax revenue, Trends, Impact, GDP, Nepal.

\section{Introduction}

Taxes are the major source of government revenue to the country in which taxes are collected from citizens, companies, investors and so on to generate economy. Taxation is considered as the principal source of government earnings, revenue is considered as the fuel of government machineries. In the modern system of governance, tax system is important which provides governments with reliable and sustainable means of revenue collection, reduces dependency on foreign aid, increase financial autonomy, enables government to provide various cash support to deserving citizens, encourages good governance, accountability and transparency, supports formalize the economy and promote economic growth etc.

Khadka (2005) has pointed that direct tax is collected directly by the government from the person who bears the tax burden. The impact and the incident are on the same person. The taxes remain under the direct tax: income tax, property tax, interest tax, capital gain tax, vehicle tax, gift tax and expenditure tax. Indirect tax is charged to person, but partly or wholly paid by another. The indirect tax imposed and incident of taxes are on different persons. Value Added Tax (VAT), excise duty, sales tax, import and export duties, entertainment tax, hotel tax.

Macek (2014) remarked that economic growth is a transitional leading to improvements in the quality of life or gradual, well-ordered socio-economic change. The empirical studies found that most of the tax structures were highly significant and related with the economic growth in a country. The change in tax policy might affect the economic planning(Marsden,1983).According to Gober and Burns (1997), a countries economy may be affect differently due to any changes in each tax components. Mahdavi (2008) has suggested that the effect of rises in total tax revenue would reduce the growth in developing countries.

\footnotetext{
Associate Professor of Saraswati Multiple Campus (Humanities Faculty: Economics Department), Tribhuvan
} University, Nepal. 
Chang(2017) has conducted a study from the perspective of regional development, the effect of raising the scale of local taxation on economic growth is the eastern region was the largest, followed by the northeastern region and central region and economic growth in the western region was the least significant. Nimenibo et al.(2018) had stated that the income earned by the government to finance its operation and invest in infrastructure development is known as government revenues. Government utilizes the collected revenues in various functions such as politics, society and economics in order to promote the social and economic welfare of a nation.

The scholars and academician research on the relationship between tax scale and economic development has focused on the macro level, which is the impact of national macro tax burden on economic growth. The Keynesian school put forward that taxation can become an effective means to stimulate the effective demand and regulate the distribution of wealth, to maintain economic stability and promote economic development.

\section{Literature Review}

There are various theories and frameworks that are used and are being discussed by various researchers and academician to investigate the relationship between taxation and economic growth. There are a large number of studies which have been carried out to investigate the relationship between taxation and economic growth. Though, the findings of those studies created conflicting results such as some studies have shown that taxes helped improve the performance of the economy while others shown that taxation reduces output and economic growth and others shown little evidence to prove strong relationship between taxation and economic growth of the emerging world economies. Solow (1956) has remarked that tax policy has an impact on economic growth by discouraging new entrepreneurial and investment incentives, distorting investment decisions and discouraging work effort and workers' acquisition of skills. Basically, the output of an economy is measured in terms of GDP and determined by its economic resources.

Myles (2000) has reviewed the theoretical and empirical evidence to assess whether a consensus arises as to how taxation affects the rate of economic growth. It has shown that the theoretical models isolate a number of channels through which taxation can affect growth and hose effects might be very substantial.

Stoilova \& Patonov ( 2012) has studied the basic trends in the distribution of the total tax burden in the EU(27) member states during the period 1995-2010. The comparative analysis has focused on the cross-country differences in terms of total tax burden, measured by the tax to GDP ratio and design tax structure, presented by the breakdown of the total tax revenues into standard components such as direct taxes, indirect taxes and social contributions. The empirical results showed a clear and strongly expressed impact of the direct taxes on economy growth. The comparison between the impacts of tax revenue accumulated by the two types of taxation confirms the assumptions for a lower efficiency of the indirect taxes as a method of budgetary revenue accumulation.

Macek (2014) has evaluated the impact of individual types of taxes on the economic growth by using regression analysis on the OECD countries. Both analyzed models confirmed the theoretical assumption that capital accumulation increases the product growth rate until it reaches the steady state. The result was statistically significant which was possible to state that the OECD countries 
have not reached the steady state. Similarly, the results of human capital impact on economic growth were in accordance with the theory. It was evident that human approximated by the ratio of at least secondary educated people on whole manpower was indeed the source of long-term economic growth.

Immanuella (2016) has investigated the contribution of VAT to the GDP growth using data obtained from Nigeria. The multiple regression analysis was applied to show the relationship between VAT revenue and GDP where he found that there has been positively related and statistical significant. The study has also found that VAT and total tax revenue were positively related and statistically significant in the Nigerian context.

Kolahi \& Noor (2016) have conducted research work to investigate the impact of VAT on GDP growth and its resources in developing countries. Panel data on 19 selected developing countries were analyzed in which the generalized moment's method (GMM) was employed. The variables that were analyzed include VAT, productivity growth, capital accumulation growth and GDP growth. The study found that VAT revenue and GDP had a positive relationship, but VAT had a negative effect on capital accumulation growth.

Takuma \& Iyke (2017) had explored the causal influence of tax revenue on economic growth in Ghana. As they remarked that taxation and economic growth have complex linkages both theoretically and empirically. The findings agree with the existing finding that taxation can influence economic growth. The policy implication is assumed to be quite clear. The policymaker can implement policies that enhance the tax scope in order to increase the revenue from taxation.

Ali \& Dalmar (2018) has found that the domestic tax revenue has a positive significant impact on economic growth but grants have a negative impact on GDP. As remarked by that grants could not be a substitute for domestic revenue generation as domestic revenue is more important of the two variables. Domestic revenue is important for enhancing economic growth and more attention should be given to the generation of domestic tax revenue.

Maganya (2020) has empirically investigated the extent which tax revenue engenders economic growth in developing countries where the author has attempted to determine the drives of economic growth in Tanzania given deliberate government actions through taxation. That study investigated empirically on the effect of taxation on economic growth between 1996/97-2019/20. The findings of that study confirmed the significant positive influence of domestic taxes on goods and services on GDP.

Neog \& Gaur (2020) have examined the long-run and short-run relationship between tax structure and state level growth performance in India. Empirical evidence from linear regression suggested that the property tax enhancing growth and commodity and service taxes reduce it. The non-linear regression validates those findings for property taxes where high property taxes are good for growth. The most promising path emerged through that study for long-run growth performance in Indian states is to lower the total tax burden and shifting from income and commodity taxes to property tax for revenue generations. 


\section{Research Objectives}

Tax revenue is the major government revenue of a country in which taxes are collected from citizens, companies, investors and so on to generate economy. There have several impacts of taxes due to economic growth and GDP whether it is positive or negative impact. Tax revenue is the major source of government expenditure of the government. The general objective of this paper is to study the overall situation of government revenue relating to GDP. The specific objectives are:

(i) To analyze the trends of tax revenue, total revenue and GDP of Nepal.

(ii) To examine the impact of tax revenue and total revenue on GDP.

\section{Data and Research Method}

The study has followed descriptive and analytical research design to analyze the data based on secondary data. To collect the views about tax revenue policy for raising the tax revenue of attraction of tax payers in Nepal. Data published by various government and non-government organizations has been used to analyze the situation. Economic survey published by Ministry of Finance, data published by Tax revenue department and Statistical Year Book and other reports published by Central Bureau of Statistics, Quarterly Economic Bulletin published by Nepal Rastra Bank. To analyze the impact of tax revenue, total revenue, government expenditure on GDP, simple linear regression model has been applied.

In the context of Nepal, it has been expected that tax revenue, total revenue and expenditure effect to economic growth as well as GDP, keeping in mind, the following model is specified to examine the impact of tax revenue, total revenue and government expenditure on GDP.

The impact of tax revenue (TxR) on GDP is estimated by:

$$
G D P_{t}=\alpha_{0}+\beta_{1} T x R_{t}+\varepsilon_{t} .
$$

Where, GDP is the gross domestic product. The $\alpha_{0}$ is constant; $\beta_{1}$ is coefficient parameter and $\varepsilon$ is the error term. The GDP is expected to be increase due to increase in tax revenue.

The impact of total revenue (TR) on GDP is estimated by:

$$
G D P_{t}=\alpha_{0}+\beta_{l} T R_{t}+\varepsilon_{t}
$$

Where, GDP is the gross domestic product, TR is the total revenue. The $\alpha_{0}$ is constant; $\beta_{1}$ and $\beta_{2}$ are coefficients parameters and - is the error or stochastic term. The GDP is expected to be increase due to increase in tax revenue and total revenue.

\section{Results and Discussion}

\section{Taxation Trends in Nepal}

Tax revenue amounted more than 80 percent to the total government revenue in Nepal. The contribution of tax revenue remains slightly variations during the study periods. The ratio of total 
revenue and tax revenue to GDP has been gradually increasing. The growth rate of GDP seems to be fluctuating in the study periods.

Table-1: Trends of Ratio of Tax Revenue and Total Revenue to GDP and Growth Rate of GDP from 2000/01-2018/19.

\begin{tabular}{|l|c|c|c|}
\hline Year & Total Revenue to GDP & Tax Revenue to GDP & GDP Growth Rate \\
\hline $2000 / 01$ & $11.90 \%$ & $9.50 \%$ & $8.20 \%$ \\
\hline $2001 / 02$ & $12.00 \%$ & $9.30 \%$ & $2.80 \%$ \\
\hline $2002 / 03$ & $11.40 \%$ & $8.70 \%$ & $7.10 \%$ \\
\hline $2003 / 04$ & $11.60 \%$ & $9.00 \%$ & $9.00 \%$ \\
\hline $2004 / 05$ & $11.90 \%$ & $9.20 \%$ & $9.80 \%$ \\
\hline $2005 / 06$ & $11.10 \%$ & $8.80 \%$ & $11.00 \%$ \\
\hline $2006 / 07$ & $12.10 \%$ & $9.80 \%$ & $11.30 \%$ \\
\hline $2007 / 08$ & $13.20 \%$ & $10.40 \%$ & $12.10 \%$ \\
\hline $2008 / 09$ & $14.50 \%$ & $11.80 \%$ & $21.10 \%$ \\
\hline $2009 / 10$ & $14.90 \%$ & $13.40 \%$ & $18.80 \%$ \\
\hline $2010 / 11$ & $14.50 \%$ & $13.00 \%$ & $13.30 \%$ \\
\hline $2011 / 12$ & $16.00 \%$ & $13.90 \%$ & $16.60 \%$ \\
\hline $2012 / 13$ & $17.50 \%$ & $15.30 \%$ & $12.40 \%$ \\
\hline $2013 / 14$ & $18.20 \%$ & $15.90 \%$ & $19.20 \%$ \\
\hline $2014 / 15$ & $19.10 \%$ & $16.70 \%$ & $9.30 \%$ \\
\hline $2015 / 16$ & $21.40 \%$ & $18.70 \%$ & $6.60 \%$ \\
\hline $2016 / 17$ & $22.80 \%$ & $20.70 \%$ & $16.00 \%$ \\
\hline $2017 / 18$ & $23.90 \%$ & $21.70 \%$ & $10.50 \%$ \\
\hline $2018 / 19$ & $24.00 \%$ & $21.40 \%$ & $14.30 \%$ \\
\hline & & & $2014 / 15$ \\
\hline
\end{tabular}

Source: Economic Surveys, 2010/11, 2014/15 \& 2019/20.

Table-1 depicts the trends of ratio of total revenue and tax revenue to GDP and growth rate of GDP from 2000/01 to 2018/19. The ratio of total revenue to GDP was 11.90 percent in 2000/01 whereas it was 24 percent in the year 2018/19. The ratio to GDP of tax revenue was 9.50 percent in $2000 / 01$ whereas it was 21.40 percent in $2018 / 19$. Similarly, the GDP growth rate was 8.20 percent in 2000/01 whereas it was 14.30 percent in 2018/19. 
Figure-1: Ratio of Total Revenue and Tax Revenue to GDP and GDP Growth Rate (Percent)

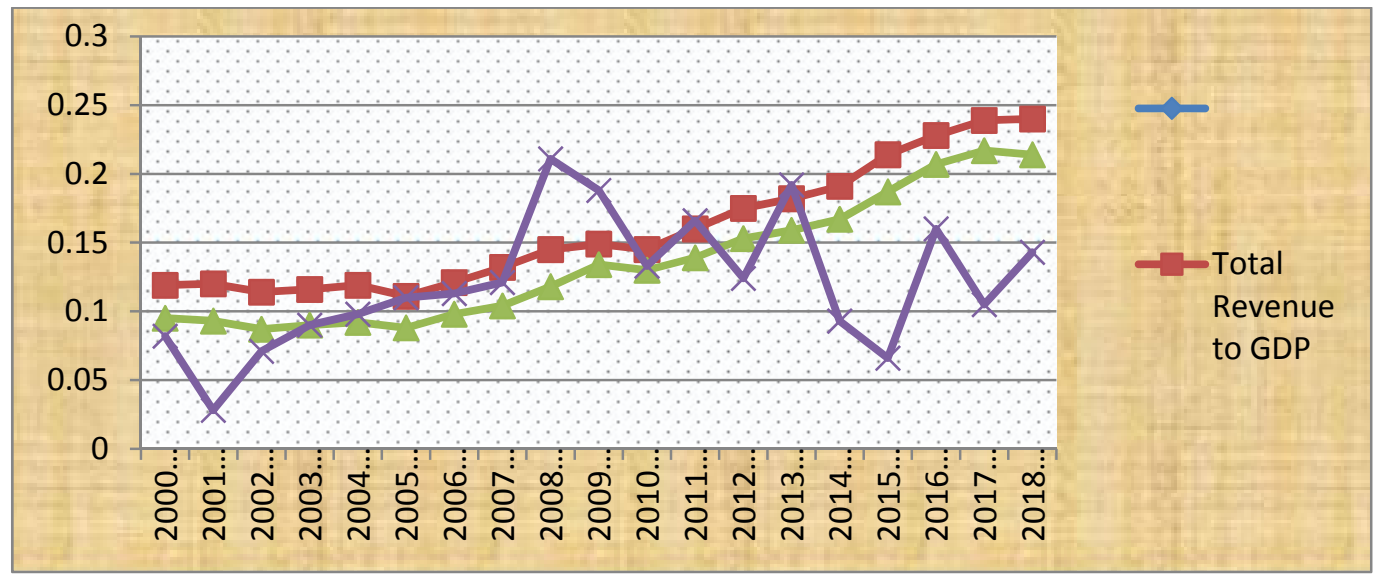

Figure-1 represents the line graph of the ratio of total revenue and tax revenue to GDP and growth trends rate of GDP. The ratio to GDP of total revenue and tax revenue are mostly increasing trends but the growth rate of GDP is found fluctuating nature.

\section{Table-2: Trends of GDP, Total Revenue and Tax Revenue from 2000/01 to} 2018/19

(Rs. in ten million)

\begin{tabular}{|c|c|c|c|c|}
\hline Year & GDP & Total Revenue & Tax Revenue & Non-Tax Revenue \\
\hline $2000 / 01$ & 44151.9 & 5564.7 & 3886.5 & 974.16 \\
\hline $2001 / 02$ & 45944.28 & 5713.16 & 3933.06 & 1111.60 \\
\hline $2002 / 03$ & 49223.13 & 6756.89 & 4089.6 & 1364.29 \\
\hline $2003 / 04$ & 53674.84 & 7361.44 & 4817.3 & 1415.80 \\
\hline $2004 / 05$ & 58941.16 & 8451.39 & 5410.47 & 1601.80 \\
\hline $2005 / 06$ & 65408.4 & 8610.96 & 5743.04 & 1485.15 \\
\hline $2006 / 07$ & 72782.7 & 10351.29 & 7112.67 & 1658.54 \\
\hline $2007 / 08$ & 81565.8 & 12794.32 & 8515.55 & 2642.26 \\
\hline $2008 / 09$ & 98805.3 & 16985.73 & 11705.19 & 2365.09 \\
\hline $2009 / 10$ & 119277.4 & 21849.17 & 15629.49 & 1820.56 \\
\hline $2010 / 11$ & 136695.4 & 19982.0 & 19837.63 & 2114.87 \\
\hline $2011 / 12$ & 152734.4 & 24437.3 & 21172.18 & 3265.12 \\
\hline $2012 / 13$ & 169501.1 & 29602.11 & 25921.49 & 3680.62 \\
\hline $2013 / 14$ & 196454.0 & 35662.08 & 31244.13 & 4417.95 \\
\hline $2014 / 15$ & 213015.0 & 40586.64 & 35595.57 & 4991.07 \\
\hline
\end{tabular}




\begin{tabular}{|c|c|c|c|c|}
\hline $2015 / 16$ & 225316.3 & 48196.16 & 42109.66 & 6086.50 \\
\hline $2016 / 17$ & 267449.3 & 60917.75 & 55386.65 & 5531.34 \\
\hline $2017 / 18$ & 304493.0 & 72671.75 & 65941.15 & 6722.60 \\
\hline $2018 / 19$ & 345879.0 & 82676.38 & 73860.4 & 8815.98 \\
\hline
\end{tabular}

Source: Economic Surveys 2003/04, 2010/11, 2013/14 \& 2019/20.

Table-2 states that the volume of GDP, total revenue and tax revenue of Nepal from 2000/01 to 2018/19. The size of GDP was Rs. 44151.9 ten million in 2000/01 whereas it has increased as Rs.345879 ten million in the year 2018/19. The total revenue was Rs. 5564.7 ten million in 2000/01 whereas it was amounted Rs.82676.368 ten million in 2018/19. The tax revenue was Rs. 3886.50 ten million in 2000/01 whereas is had reached Rs. 73860.40 ten million in 2018/19. The size of GDP, total revenue and tax revenue have found significantly increased during the study periods.

\section{Economic Impact}

There has been relationship between total revenue, tax revenue, government expenditure and economic growth due to the fact the state uses as a controlling economy instrument the fiscal policy.

\section{Impact of Tax Revenue on GDP}

There is significant positive impact of tax revenue on GDP. Tax revenue influences the economic growth of the economy. In order to find the impact of tax revenue on GD, the GDP was regressed on tax revenue. The overall model is statistically significant $\left(\mathrm{R}^{2}=0.980, \mathrm{p}<0.05\right)$. This means that increase in GDP is related to increase in tax revenue. Similarly, R-square value states that 98 $\%$ change in GDP is due to independent variable tax revenue. The result shows that there is a significant impact of tax revenue on GDP. The finding of the regression analysis between tax revenue and GDP indicates that tax revenue is a significant predictor of GDP (Table-3).

\section{Table-3: Regression between Tax Revenue and GDP}

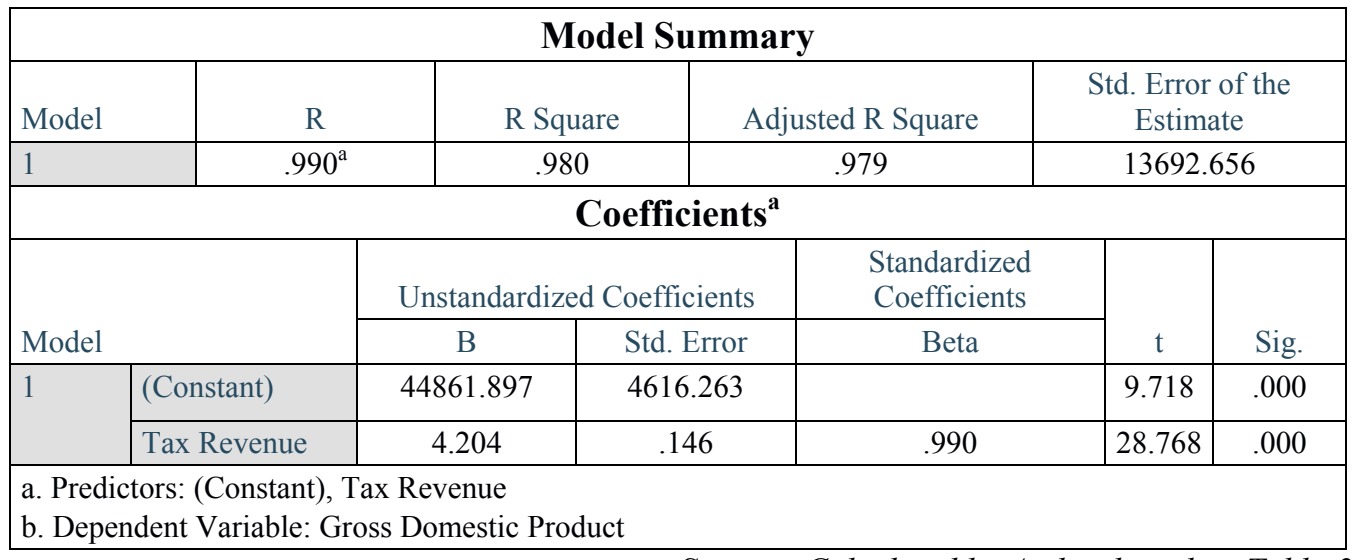

Source: Calculated by Author based on Table-2. 


\section{Impact of Total Revenue on GDP}

There is relationship between government expenditure and total revenue on GDP. There is positive relationship between total revenue and GDP. (Table-4).

Table-4: Regression between Total Revenue and GDP

\begin{tabular}{|c|c|c|c|c|c|c|}
\hline \multicolumn{7}{|c|}{ Model Summary } \\
\hline Model & $\mathrm{R}$ & R Square & Adjusted R Square & Std. Error of the Estimate & \multicolumn{2}{|c|}{$\begin{array}{l}\text { Durbin- } \\
\text { Watson }\end{array}$} \\
\hline 1 & $.991^{\mathrm{a}}$ & .981 & .979 & 13579.738 & \multicolumn{2}{|c|}{.473} \\
\hline \multicolumn{7}{|c|}{ Coefficients $^{a}$} \\
\hline \multirow{2}{*}{\multicolumn{2}{|c|}{ Model }} & \multicolumn{2}{|c|}{ Unstandardized Coefficients } & \multirow{2}{*}{$\begin{array}{c}\text { Standardized Coefficients } \\
\text { Beta } \\
\end{array}$} & \multirow[b]{2}{*}{$\mathrm{t}$} & \multirow[b]{2}{*}{ Sig. } \\
\hline & & $\mathrm{B}$ & Std. Error & & & \\
\hline \multirow[t]{2}{*}{1} & (Constant) & 35078.628 & 4830.844 & & 7.261 & .000 \\
\hline & Total Revenue & 4.785 & .628 & 1.208 & 7.624 & .000 \\
\hline
\end{tabular}

Source: Calculated by Author based on Table-2.

This study has also tried to examine the impact of total revenue on GDP. This study finds that increase in total revenue results increase in GDP. In order to test the impact of total revenue on GDP, the GDP was regressed on total revenue using data of 2000/01-2018/19. The regression fit $\left(\mathrm{R}^{2}=0.981\right)$ because the overall relationship is statistically significant. The relationship between total revenue and GDP is significant at 5 percent critical value.

\section{Conclusions}

The aim of the study was to examine the impact of tax revenue, total revenue and government expenditure on GDP of Nepal. The changes in the level of revenues and changes in the stricture of tax system can influence economic activity. The study showed a clear and strongly impact of the tax revenue and total revenue on GDP. There is significant positive impact of tax revenue on GDP. Tax revenue influences the economic growth of the economy. This study has also tried to examine the impact of total revenue on GDP. This study finds that increase in total revenue results increase in GDP. In fact, a fair assessment would conclude that well-designed tax policies have the potential to raise economic growth, but there are many stumbling blocks along the way and certainly no guarantee that all tax changes will improve economic performance.

The size of sources of government revenue is smaller than the size of government expenditure. The tax revenue covers more than eighty percent whereas non-tax revenue represents around twenty percent. Basically financial deficiency covers by accepting foreign grants and debt. In each and every year, the volume of public debt has been expanding in Nepal. For reducing the reducing the volume of public debt, government should increase the areas of tax revenue and make it tax paying friendly environment. 


\section{References}

Ali, A. Ali, Y.S. and Dalmar, M.S.(2018). The Impact of Tax Revenue on Economic Growth: Time Series Evidence from Kenya. Academic Research International, Vol.9(3), September 2018, pp.163-170.

Chang,F.(2017). Local Tax Scale and Its Economic Effects in China. Modern Economy, 8, pp.445457. DOI : 10.4236/me.2017.83033.

Gober, J.R. \& Burns, J.O.(1997). The Relationship between Tax Structure and Economic Indicators. Journal of International Accounting, Auditing and Taxation 6,pp.1-24

Gujarati, D.N.(2004). Basic Econometrics. New York: McGraw-Hill/Irwin.

Immanauella, O.(2016). Evaluation of the Contribution of Value Added Tax to Nigeria Economy. EPRA International Journal of Economic and Business Review, Vol.4 (2), pp.32-46.

Khadka,R.B.(2005). Moderning Tax Administration in Nepal. Kathmandu: Pairavi Prakashan.

Kolahi, S.H. \& Noor, Z.B.(2016). The Effect of Value Added Tax on Economic Growth and Its Sources in Developing Countries. International Journal of Economics and Finance, Vol.8 (1), 217-228.

Macek, R.(2014). The Impact of Taxation on Economic Growth : Case Study of OECD Countries. Review of Economic Perspectives. Vol. 14, Issue 4, pp.309-328.

Mahdavi,S.(2008). The Level and Composition of Tax Revenue in Developing Courtiers: Evidence from Unbalanced Panel Data. International Review of Economics \& Finance, 17(4) : 607-617.

Managya, M.H.(2020). Tax Revenue and Economic Growth in Developing Country: An Autoregressive Distribution Lags approach. Central European Economic Journal, Vol.7, Issue 54. pp. 205-217. https://doi.org/10.2478/ceej-2020-0018.

Marsden.K.(1983). Links between Taxes and Economic Growth: Some Empirical Evidence. World Bank Staff Working Papers, No.605, 21-25.

Ministry of Finance (2010). Economic Survey 2010/11. Kathmandu: Government of Nepal.

Ministry of Finance (2010). Economic Survey 2019/201. Kathmandu: Government of Nepal.

Ministry of Finance (2014). Economic Survey 2014/15. Kathmandu: Government of Nepal.

Ministry of Finance (2020). Inland Revenue Department of Nepal. Kathmandu : Government of Nepal.

Myles,G.D.(2000). Taxation and Economic Growth. Fiscal Studies, Vol.21, No.1, pp.141-168.

Neog, Y. \& Gaur, A.K.(2020). Tax Structure and Economic Growth: A Study of Selected Indian States. Journal of Economics Structures, Vol.9 (38). $\quad$ https://doi.org/10.1186/s4008$\underline{020-00215-3}$. 
Nimenibo, A. et al.(2018). An Empirical Analysis of Tax Revenue and Economic Growth in Nigeria from 1980-2015. Global Journal of Human Social Science Research,18(3),pp.9-40.

Solow, R.M.(1956). A Contribution to the Theory of Economic Growth. The Quarterly Journal of Economics.Vol.70 (1), February 1956, pp.65-94. https:// doi.org/10.2307/1884513.

Stoilova,D. \& Patonov, N.(2012). An Empirical Evidence for the Impact of Taxation on Economy Growth in the European Union. Book of Proceedings: Tourism and Management Studies International Conference Algarve 2012, Vol.3, Portugal.

Takuma, W. \& Iyke, B.N.(2017). The Links between Economic Growth and Tax Revenue in Ghana: An Empirical Investigation. International Journal of Sustainable Economy, Vol.9, No.1, pp.34-55. MPRA Paper. 